\title{
Can VAP-1 Protein be used as a Biomarker in Thyroid Cancer?
}

\author{
VAP-1 Proteini Tiroid Kanserinde Biyobelirteç Olarak Kullanılabilir mi?
}

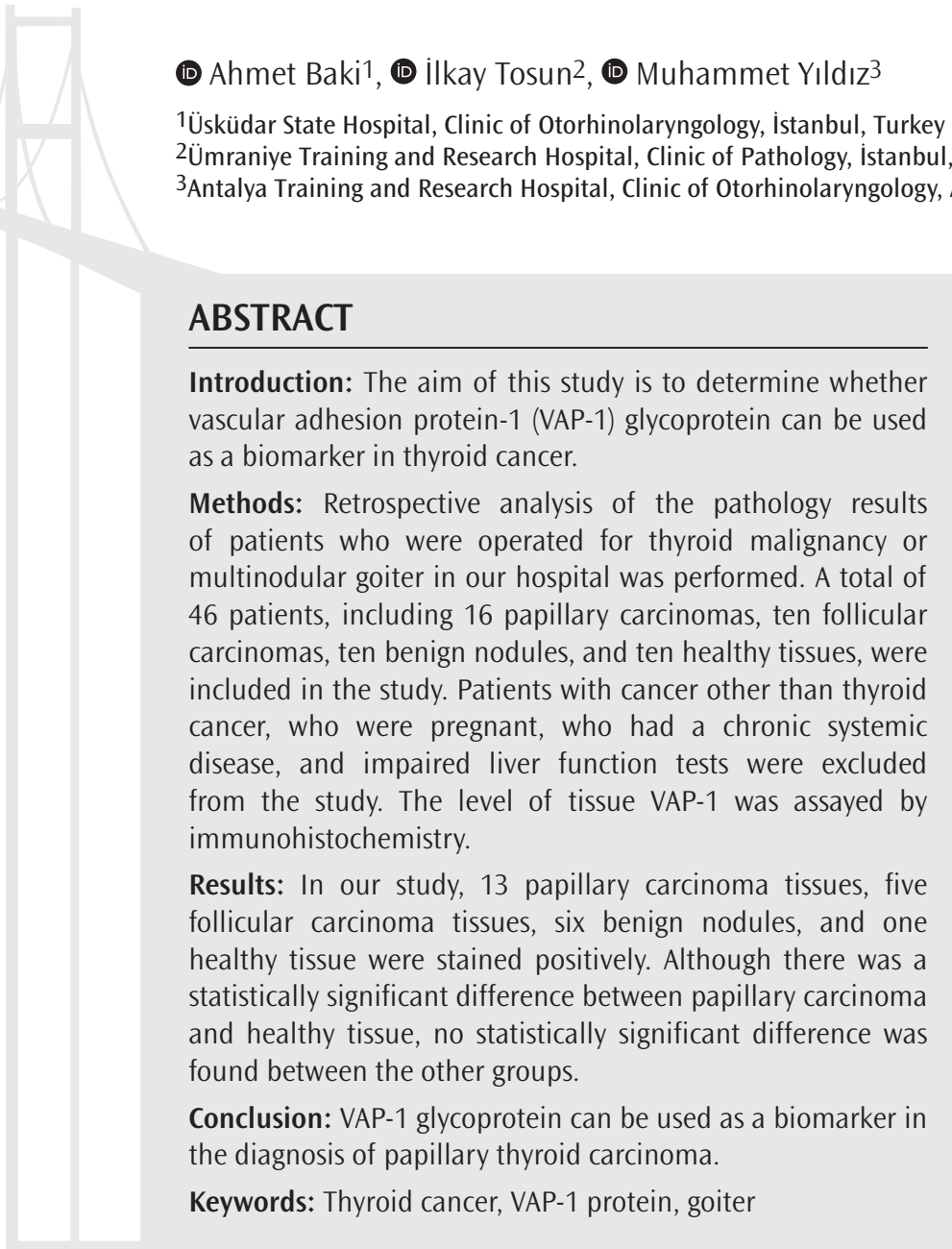

öZ

Amaç: Bu çalışmanın amacı, vasküler adhezyon proteini-1 (VAP-1) glikoproteinin tiroid kanserinde biyobelirteç olarak kullanılıp kullanılamayacă̆ını belirlemektir.

Yöntemler: Hastanemizde tiroid malignitesi veya multinodüler guatr nedeniyle opere edilen hastaların patoloji sonuçlarının retrospektif analizi yapıldı. Çalışmaya 16 papiller karsinom, on foliküler karsinom, on iyi huylu nodül ve on sağlıklı doku olmak üzere toplam 46 hasta alındı. Tiroid kanseri dışında kanseri olan, gebe olan, kronik sistemik hastalığı olan ve karaciğer fonksiyon bozukluğu olan hastalar çalıșma dıșı bırakıldı. Doku VAP-1 seviyesi immünohistokimya ile test edildi.

Bulgular: Çalışmamızda 16 papiller karsinom olgusunun 13'ü, 10 foliküler karsinom olgusunun 5'i, 10 benign dokunun 6'sı ve 10 normal dokunun 1'i pozitif olarak boyanırken diğer olgular negatif olarak boyandı. Papiller karsinom ve normal doku arasında istatistiksel olarak anlamlı bir fark olmasına rağmen, diğer gruplar arasında istatistiksel olarak anlamlı bir fark bulunmadı.

Sonuç: VAP-1 glikoprotein papiller tiroid karsinomu tanısında biyobelirteç olarak kullanılabilir.

Anahtar Kelimeler: Tiroid kanseri, VAP-1 proteini, guatr

\section{Introduction}

Thyroid cancer is a common disease among head and neck cancers, and the incidence of it has been increasing all around the world (1). The fiveyear survival is only $59 \%$ in late-stage compared to nearly $100 \%$ for an earlier, localized stage (2).

Most of the patients present with a thyroid nodule, but only $5-15 \%$ of nodules are malignant (3). One of the most effective methods of decreasing mortality is the early diagnosis, and fine-needle aspiration cytology (FNAC) is most commonly used for this purpose (4). The use of FNAC can reduce unnecessary thyroid operations by $25 \%$ (5). Although malignant nodules can be detected by FNAC, $10 \%$ to $25 \%$ of thyroid nodules are diagnosed as indeterminate nodules (6). FNAC results may vary from non-specific cytology to malignancy, but as a result, the biomarker may be needed to support this outcome preoperatively. Given the limitations of diagnosis by FNAC, investigators have examined molecular markers as cytopathologic adjuncts to improve the accuracy of diagnostic testing of thyroid nodules. A major aim of the research is to 
improve upon the preoperative diagnosis of indeterminate nodules in order to avoid surgery for benign nodules. To reduce repetitive diagnostic tests and operations, there has been an extensive investigation into molecular markers that can be detected on FNAC specimens to stratify a patient's risk of malignancy more accurately.

Many biomarkers are used to differentiate between benign and malignant thyroid nodules, including cytokeratin-19, fibronectin-1, intracellular sodium/iodide, high molecular weight cytokeratin, cyclin D1, and galectin-3 $(7,8)$. They can be used alone or in combination. A single biological marker is not yet able to distinguish between benign or malignant thyroid nodules. The ideal biomolecule that can make this distinction has long been the subject of research.

Vascular adhesion protein-1 (VAP-1), which is another promising glycoprotein marker, weighs $170 \mathrm{kDa}$. This protein is an endothelial adhesion molecule generally involved in the interaction between leukocytes and endothelial cells, including leukocyte rolling, adhesion, and transmigration into sites of inflammation (9). Recently, many studies have investigated the role of VAP-1 in cancers. In the head and neck, liver, and melanoma tumors, VAP-1 expression is found in intra-tumoral vessels (10-12). VAP-1 has been shown to enhance tumor growth in mice (13). In humans, serum VAP-1 is correlated with angiogenic factors in lung cancers and is more concentrated in metastatic prostatic cancers $(14,15)$.

The primary aim of this study was to investigate tissue VAP-1 levels in benign and malignant thyroid lesions and to compare them with healthy tissue levels. We also aimed to determine whether VAP-1 could be used as a biomarker in thyroid cancer.

\section{Methods}

The pathology specimens of patients who underwent total thyroidectomy for thyroid malignancy or multinodular goiter were examined. The study was carried out in four groups, including papillary carcinoma, follicular carcinoma, benign tissue, and healthy tissue. The pathologic tissues of 53 patients were retrospectively reviewed. Patients with other cancers other than thyroid cancer, who were pregnant, who had a chronic systemic disease, and impaired liver function tests were excluded from the study. Of the 46 patients included in the study, 16 were papillary thyroid carcinoma (PTC), ten were follicular thyroid carcinoma (FTC), ten were benign nodules, and ten were healthy patients. Thyroid cancer patients underwent total thyroidectomy and neck dissection. The American Common Cancer Committee TNM classification system was used for staging. Our study was approved by the Ethics Committee of Ümraniye Training and Research Hospital (decision no: 165, date: 24.11.2017). For the study, approval was obtained from the patients.

\section{Laboratory Study}

VAP-1 (A-8: sc-166713; Santa Cruz Biotechnology) clone was used as the primary antibody. Paraffin blocks suitable for immunohistochemical analysis were selected, and 3-micron thick sections were taken on the poly-L-lysine coated slide. The immunohistochemical study was completed automatically on the VENTANA BENCHMARK XT device by the device instructions. The staining patterns in the tissue were evaluated as negative and positive.

\section{Statistical Analysis}

In this study, IBM SPSS Statistics Version 22 (IBM Turkish Limited Company, İstanbul, Turkey) program was used for statistical analysis. Descriptive statistical methods (mean, standard deviations, and median value) were calculated. When the groups were evaluated together nonparametric data were assessed by the chi-square test. We performed a receiver operating characteristic (ROC) curve analysis to evaluate the predictive value of VAP-1 for papillary thyroid cancer. Significance was assessed at $p<0.05$ levels.

\section{Results}

There were 46 patients in our study. Sixteen of the patients had PTC, ten of them had the FTC, ten with benign tissue, and ten with healthy tissue. The mean age of the patients included in the study was 43.6 \pm 5.2 , $42.7 \pm 5.7,43.7 \pm 4.7$, and $43.4 \pm 5.2$ years, respectively. Thyroglobulin (ng/ $\mathrm{mL}$ ) levels of the patients were higher in cancer patients than in benign and healthy tissues. In PTC and FTC patients, it was found to be $89.4 \pm 56.7$ and $88.7 \pm 55.2$, whereas it was $15.2 \pm 13.6$ and $11.3 \pm 10.4$ in benign tissue and healthy tissue, respectively. FT4 (pmol/L), thyroid-stimulating hormone $(\mu \mathrm{IU} / \mathrm{mL})$ values, and liver function tests were normal in all groups. Of the PTC patients, 14 were stage 1-2, two were stage 3-4, while eight of the FTC patients were stage 1-2, and two were stage 3-4 (Table 1).

In tissue staining, 13 of the PTC, five of the FTC, seven of the benign nodules, and one of the healthy tissues were stained positively while the others were negatively stained (Figure 1, 2) (Table 2).

\begin{tabular}{|c|c|c|c|c|}
\hline Characteristics & Papillary carcinoma & Follicular carcinoma & Benign tissue & Healthy tissue \\
\hline Age & $43.6 \pm 5.2(n=16)$ & $42.6 \pm 5.7(n=10)$ & $43.7 \pm 4.7(n=10)$ & $43.4 \pm 5.2(n=10)$ \\
\hline $\operatorname{Tg}(\mathrm{ng} / \mathrm{mL})$ & $89.4 \pm 56.7$ & $88.7 \pm 55.2$ & $15.2 \pm 13.6$ & $11.3 \pm 10.4$ \\
\hline FT4 (pmol/L) & $12.5 \pm 4.7$ & $13.4 \pm 3.8$ & $14.1 \pm 2.6$ & $11.50-23.12$ \\
\hline TSH $(\mu \mathrm{IU} / \mathrm{mL})$ & $3.5 \pm 3.1$ & $3.6 \pm 3.4$ & $3.2 \pm 2.3$ & $3.1 \pm 1.6$ \\
\hline Hepatic disease & - & - & - & - \\
\hline Systemic disease & - & - & - & - \\
\hline Thyroid cancer stage & - & - & - & - \\
\hline I/II (n, \%) & $14(87.5 \%)$ & $8(80 \%)$ & - & - \\
\hline III/IV (n, \%) & $2(12.5 \%)$ & $2(20 \%)$ & - & - \\
\hline
\end{tabular}


When all groups were compared, a statistically no significant difference was found ( $p=0.48$ ) (Table 3). Although there was a statistically significant difference in comparisons between PTC and healthy tissue groups $(p<0.01)$, respectively, no significant difference was found between the other groups ( $p=1),(p=0,52),(p=1),(p=1),(p=0.52)$ (Table 4).
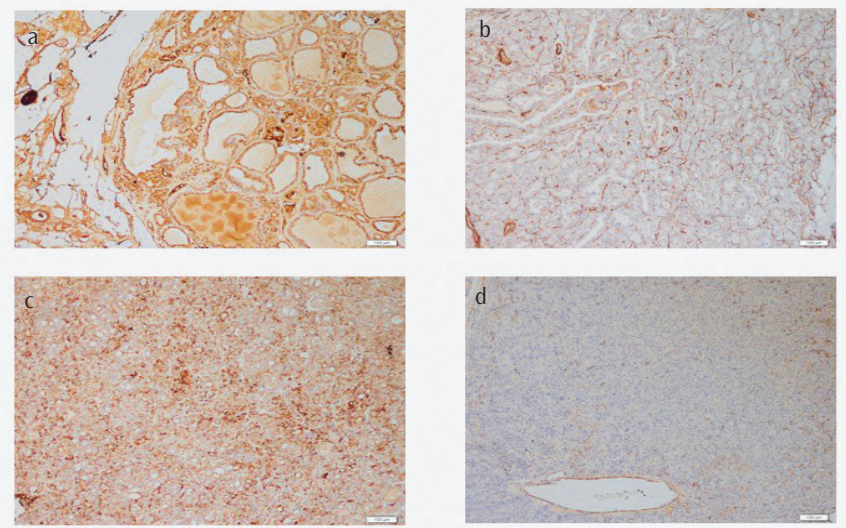

Figure 1. a) Papillary carcinoma positive staining. b) Papillary carcinoma negative staining. c) Follicular carcinoma positive staining. d) Follicular carcinoma negative staining

\section{Table 2. Staining characteristics of the patients}

\begin{tabular}{|l|l|l|}
\hline & Positive stained & Negative stained \\
\hline Normal tissue & n & n \\
\hline Benign nodule & 7 & 9 \\
\hline Papillary cancer & 13 & 3 \\
\hline Follicular cancer & 5 & 3 \\
\hline n: number of patients & & 5 \\
\hline
\end{tabular}

The area under the ROC curve was 0.83 (95\% confidence interval, 0.65$1 ; p=0.007)$. The decision on optimal cut off value for tissue VAP-1 was based on maximizing the sum of sensitivity and specificity. The cut-off value of VAP-1 was $0.5 \mu \mathrm{g} / \mathrm{mL}$, with a $78 \%$ specificity and $100 \%$ sensitivity (Figure 3).
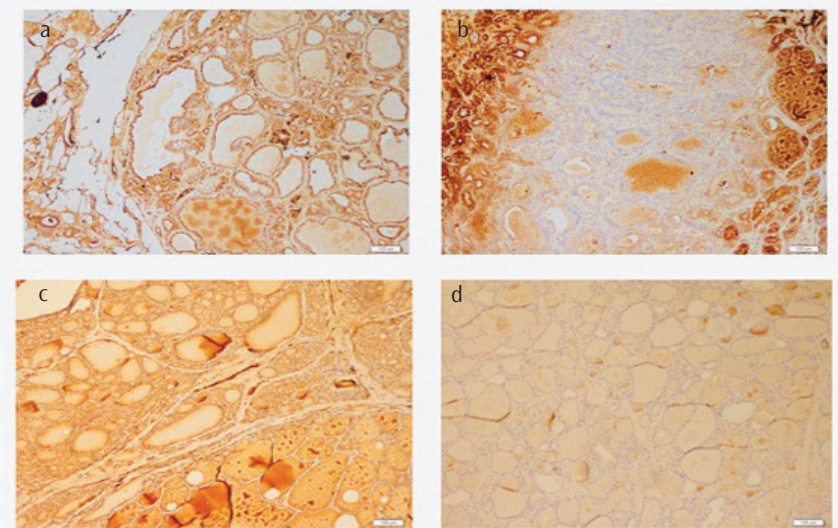

Figure 2. a) Benign tissue positive staining. b) Benign tissue negative staining. c) Healthy tissue positive staining. d) Healthy tissue negative staining

Table 3. Comparison of all groups together

\begin{tabular}{|l|l|l|l|}
\hline Papillary cancer & 16 & & \\
\hline Follicular cancer & 10 & \multirow{2}{*}{6.66} & 0.48 \\
\hline Benign nodule & 10 & & \\
\hline Normal tissue & 10 & & \\
\hline
\end{tabular}

Chi-square test, $\mathrm{N}$ : number of patients, $\mathrm{p}$ value $\leq 0.05$

Table 4. Comparison of binary groups

\begin{tabular}{|c|c|c|c|}
\hline Comparison of papillary cancer and normal tissue & $\mathrm{n}$ & $x^{2}$ & $p$ \\
\hline Papillary cancer & 16 & \multirow{2}{*}{6.25} & \multirow{2}{*}{$0.01 *$} \\
\hline Normal tissue & 10 & & \\
\hline Comparison of papillary cancer and follicular cancer groups & n & $x^{2}$ & $\mathrm{p}$ \\
\hline Papillary cancer & 16 & \multirow{2}{*}{6.25} & \multirow{2}{*}{1} \\
\hline Follicular cancer & 10 & & \\
\hline Comparison of papillary and benign nodules & $\mathrm{n}$ & $x^{2}$ & $\mathrm{p}$ \\
\hline Papillary cancer & 16 & \multirow{2}{*}{6.25} & \multirow{2}{*}{0.52} \\
\hline Benign nodule & 10 & & \\
\hline Comparison of follicular cancer and benign nodules & $\mathrm{n}$ & $x^{2}$ & $\mathrm{p}$ \\
\hline Follicular cancer & 10 & \multirow{2}{*}{0.00} & \multirow{2}{*}{1} \\
\hline Benign nodule & 10 & & \\
\hline Comparison of follicular cancer and normal tissue & $\mathrm{n}$ & $x^{2}$ & $\mathrm{p}$ \\
\hline Follicular cancer & 10 & \multirow{2}{*}{0.00} & \multirow[t]{2}{*}{1} \\
\hline Normal tissue & 10 & & \\
\hline Benign nodule and normal tissue comparison & n & $x^{2}$ & p \\
\hline Benign nodule & 10 & \multirow{2}{*}{0.40} & \multirow{2}{*}{0.52} \\
\hline Normal tissue & 10 & & \\
\hline
\end{tabular}




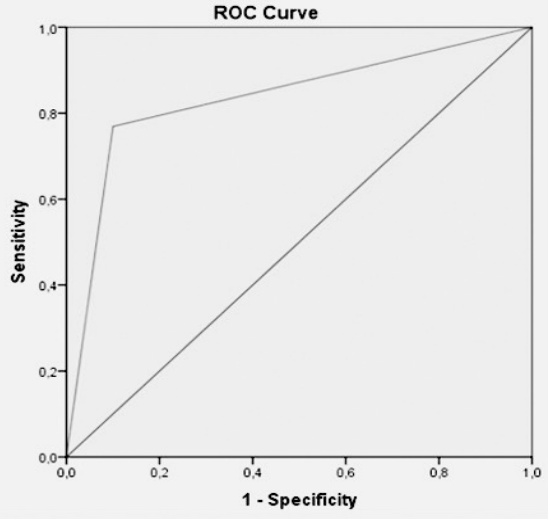

Figure 3. Receiver operating characteristic (ROC) curve. Tissue VAP-1 staining in papillary thyroid cancer and healthy tissue were used to draw the ROC curve, and the specificity, sensitivity, area under the ROC curve (AUC), and cut-off value were determined

VAP-1: vascular adhesion protein-1, AUC: area under the curve

\section{Discussion}

Biomarkers have been used for many years to detect thyroid cancer and to determine its prognosis (16). A marker that can identify benign and malignant thyroid nodules and predict their behavior is continuously sought. Difficulties in identifying thyroid nodules and determining their prognosis persist (17). For thyroid nodules, an accurate biomarker is necessary to measure the likelihood of preoperative malignancy.

The process of tumor growth and metastasis involves a variety of cellcell and cell-extracellular matrix interactions mediated by cell adhesion molecules such as intercellular adhesion molecule-1, vascular cell adhesion molecule-1, platelet endothelial cell adhesion molecule-1, and selectins. During tumor growth and metastasis, each process requires cell adhesive interactions involving specific adhesion molecules and receptors $(18,19)$. VAP-1 is one of the endothelial adhesion molecules, which is upregulated at sites of inflammation and mediates binding of lymphocytes to vessels of inflamed tissue (20). In many studies, serum VAP-1 levels are a significant predictor of the prognosis of cancer diseases.

The tissue and serum VAP-1 protein levels were significantly lower in colorectal cancer compared with healthy colon tissue (21). The low serum VAP-1 was associated with poor prognosis in patients with colorectal cancer (22). The low tissue VAP-1 may be part of a mechanism used by the tumor to prevent the recruitment of antitumor defense cells (21). The serum concentration of VAP-1 was significantly elevated in patients with gastric cancer, and clinicopathological analysis revealed that low serum VAP-1 levels in tumors were associated with tumor size increase, serosal invasion, lymph node metastasis, peritoneal dissemination and poor prognosis (23). Serum VAP-1 levels were also found higher in patients with hepatocellular cancer (24). In human breast cancer, tumor VAP-1 mRNA expression is associated with improved prognosis $(25,26)$. In contrast, increased VAP-1 protein expression was found to be associated with poor prognosis in astrocytomas (27).

$\mathrm{Hu}$ et al. (28) find that serum VAP-1 levels are significantly lower in thyroid cancer group than in healthy control and benign thyroid nodule groups. Another important finding of their study is that serum VAP-1 has relatively high sensitivity and specificity in predicting thyroid cancer. In this study, we evaluated VAP-1 protein expression in different thyroid pathologies and healthy thyroid tissue at tissue level for the first time in the literature. In our study, 13 of 16 cases of PTC, five of ten cases of FTC, six of ten benign tissues, and one of ten healthy tissues were stained positively. Although there was a statistically significant difference between PTC and healthy tissue, no statistically significant difference was found between the other groups. The cut-off value of VAP-1 was $0.5 \mu \mathrm{g} / \mathrm{mL}$, with a $78 \%$ specificity and $100 \%$ sensitivity for papillary carcinoma. Therefore, the combined application of ultrasonographic features and VAP-1 examination in FNA material could be a potential way to improve the accuracy of diagnosing PTC.

It was shown that the genes encoding chemokines CCL20, CXCL8, and the adhesion molecule L-selectin were overexpressed in PTC in comparison to healthy thyroid tissue, and these chemokines could be associated with tumor-related inflammation and lymphocyte infiltration (29). In human PTC, the density of lymphocytes is correlated with improved overall survival and lower recurrences $(30,31)$. In our study, the rate of VAP-1 staining was higher in patients with PTC than in healthy tissues. This may be because the VAP-1 protein has a significant lymphocyte infiltration and migration effect, and the expression is increased to prevent the progression of the disease in cancer tissue.

FTC comprises between $10 \%$ and $15 \%$ of all differentiated thyroid cancers. This cancer usually presents later in life and is more aggressive than PTC $(32,33)$. It is a malignant epithelial tumor showing follicular cell differentiation and lacking the nuclear diagnostic features of PTC (34). In this study, VAP-1 protein staining was found in half of the patients with FTC. However, statistical results could not be obtained to support the use of VAP-1 protein as a biomarker in this cancer type. Also, less VAP-1 staining in FTC than PTC may explain that the prognosis of FTC is worse than papillary cancer. Further studies are needed to investigate the effects of tissue VAP-1 protein expression on prognosis in FTC.

In this study, tissue VAP-1 protein staining was detected in six of ten patients with benign thyroid nodules. VAP-1 is upregulated at sites of inflammation, and it mediates lymphocyte binding to inflamed endothelium (35). Increased serum VAP-1 levels in chronic liver disease and multiple sclerosis compared to healthy individuals has been reported previously $(36,37)$. Since VAP-1 levels can be detected in inflammatory tissues besides cancers, we thought that positivity detected in benign nodules might be related to inflammation at the tissue level. New data are needed to explain the pathophysiology of VAP-1 staining in benign thyroid nodules at the tissue level and the importance of this staining.

FNAC results may not yield accurate results in thyroid nodules, so positive or negative staining of FNAC material with VAP-1 protein may be helpful in the differential diagnosis. As a result, positive staining of VAP-1 protein in FNAC results may stimulate us for the diagnosis of papillary cancer. It can also help reduce the patient's follow-up or additional cost tests. To demonstrate that VAP-1 protein can be used as an important biomarker in thyroid cancer, studies may be needed in larger series. Further studies are needed to investigate the prognostic effects of VAP-1 on TPC. 


\section{Conclusions}

Different amounts of VAP-1 staining were obtained in different thyroid pathologies. VAP-1 protein can be used as an important biomarker in TPC.

Ethics Committee Approval: Our study was approved by the Ethics Committee of Ümraniye Training and Research Hospital (decision no: 165, date: 24.11.2017).

Informed Consent: For the study, approval was obtained from the patients.

Peer-review: Externally peer-reviewed.

Author Contributions: Surgical and Medical Practices - I.T.; Concept A.B.; Design - A.B.; Data Collection and/or Processing - A.B., I.T.; Analysis and/or Interpretation - A.B., I.T., M.Y.; Literature Search - A.B., M.Y.; Writing Manuscript - A.B., M.Y.

Conflict of Interest: No conflict of interest was declared by the authors.

Financial Disclosure: Our special thanks Ser-med medical and MedersMaxton corporation for their financial support.

\section{References}

1. Zhou ZH, Cui XN, Xing HG, Yan RH, Yao DK, Wang LX. Changes and prognostic value of serum vascular endothelial growth factor in patients with differentiated thyroid cancer. Med Princ Pract 2013; 22: 24-8.

2. Kunavisarut T. Diagnostic biomarkers of differentiated thyroid cancer. Endocrine 2013; 44: 616-22.

3. Cooper DS, Doherty GM, Haugen BR, Kloos RT, Lee SL, Mandel SJ, et al. Revised American Thyroid Association management guidelines for patients with thyroid nodules and differentiated thyroid cancer. Thyroid 2009; 19: 1167214.

4. Castro MR, Gharib H. Continuing controversies in the management of thyroid nodules. Ann Intern Med 2005; 142: 926-31.

5. Gharib H, Goellner JR. Fine-needle aspiration biopsy of the thyroid: an appraisal. Ann Intern Med 1993; 118: 282-9.

6. Rosen JE, Stone MD. Contemporary diagnostic approach to the thyroid nodule. J Surg Oncol 2006; 94: 649-61.

7. Park YJ, Kwak SH, Kim DC, Kim H, Choe G, Park DJ, et al. Diagnostic value of galectin-3, HBME-1, cytokeratin 19, high molecular weight cytokeratin, cyclin D1 and p27 (kip1) in the differential diagnosis of thyroid nodules. J Korean Med Sci 2007; 22: 621-8.

8. Bartolazzi A, Sciacchitano S, D'Alessandria C. Galectin-3: The impact on the clinical management of patients with thyroid nodules and future perspectives. Int J Mol Sci 2018; 19. pii: E445.

9. Merinen M, Irjala H, Salmi M, Jaakkola I, Hänninen A, Jalkanen S. Vascular adhesion protein-1 is involved in both acute and chronic inflammation in the mouse. Am J Pathol 2005; 166: 793-800.

10. Yoong KF, McNab G, Hubscher SG, Adams DH. Vascular adhesion protein-1 and ICAM-1 support the adhesion of tumor-infiltrating lymphocytes to tumor endothelium in human hepatocellular carcinoma. J Immunol 1998; 160: 3978-88.

11. Irjala H, Salmi M, Alanen K, Grenman R, Jalkanen S. Vascular adhesion protein 1 mediates binding of immunotherapeutic effector cells to tumor endothelium. J Immunol 2001; 166: 6937-43.

12. Forster-Horváth C, Döme B, Paku S, Ladányi A, Somlai B, Jalkanen S, et al. Loss of vascular adhesion protein-1 expression in intratumoral microvessels of human skin melanoma. Melanoma Res 2004; 14: 135-40.
13. Marttila-Ichihara F, Auvinen K, Elima K, Jalkanen S, Salmi M. Vascular adhesion protein-1 enhances tumor growth by supporting recruitment of Gr-1 + CD11b + myeloid cells into tumors. Cancer Res 2009; 69: 7875-83.

14. Garpenstrand H, Bergqvist M, Brattström D, Larsson A, Oreland L, Hesselius P, et al. Serum semicarbazide-sensitive amine oxidase (SSAO) activity correlates with VEGF in non-small-cell lung cancer patients. Med Oncol 2004; 21: 241-50.

15. Ekblom J, Gronvall J, Lennernas B, Nilsson S, Garpenstrand H, Oreland L. Elevated activity of semicarbazide-sensitive amine oxidase in blood from patients with skeletal metastases of prostate cancer. Clin Sci (Lond) 1999; 97: $111-5$.

16. Daniels GH. What is the role of molecular markers in the management of "indeterminat" thyroid nodules? Cancer Cytopathol 2013; 121: 223-4.

17. Scheffler P, Forest VI, Leboeuf R, Florea AV, Tamilia M, Sands NB, et al. Serum thyroglobulin improves the sensitivity of the McGill Thyroid Nodule Score for well-differentiated thyroid cancer. Thyroid 2014; 24: 852-7.

18. Albelda SM. Role of integrins and other cell adhesion molecules in tumor progression and metastasis. Lab Invest 1993; 68: 4-17.

19. Ponta H, Sleeman J, Herrlich P. Tumor metastasis formation: cell-surface proteins confer metastasis-promoting or -suppressing properties. Biochim Biophys Acta 1994; 1198: 1-10.

20. Salmi M, Jalkanen S. A 90-kilodalton endothelial cell molecule mediating lymphocyte binding in humans. Science 1992; 257: 1407-9.

21. Ward ST, Weston CJ, Shepherd EL, Hejmadi R, Ismail T, Adams DH. Evaluation of serum and tissue levels of VAP-1 in colorectal cancer. BMC Cancer 2016; 16: 154 .

22. Toiyama Y, Miki C, Inoue $\mathrm{Y}$, Kawamoto A, Kusunoki M. Circulating form of human vascular adhesion protein-1 (VAP-1): decreased serum levels in progression of colorectal cancer and predictive marker of lymphatic and hepatic metastasis. J Surg Oncol 2009; 99: 368-72.

23. Yasuda H, Toiyama Y, Ohi M, Mohri Y, Miki C, Kusunoki M. Serum soluble vascular adhesion protein-1 is a valuable prognostic marker in gastric cancer. J Surg Oncol 2011; 103: 695-9.

24. Kemik O, Sümer A, Kemik AS, Itik V, Dulger AC, Purisa S, et al. Human vascular adhesion proteın-1 (VAP-1): serum levels for hepatocellular carcinoma in nonalcoholic and alcoholic fatty liver disease. World J Surg Oncol 2010; 8: 83

25. Chen HW, Huang HC, Lin YS, Chang KJ, Kuo WH, Hwa HL, et al. Comparison and identification of estrogen-receptor related gene expression profiles in breast cancer of different ethnic origins. Breast Cancer (Auckl) 2008; 1: 35-49.

26. Sotiriou C, Neo SY, McShane LM, Korn EL, Long PM, Jazaeri A, et al. Breast cancer classification and prognosis based on gene expression profiles from a population-based study. Proc Natl Acad Sci USA 2003; 100: 10393-8.

27. Kostoro J, Chang SJ, Clark Lai YC, Wu CC, Chai CY, Kwan AL. Overexpression of vascular adhesion protein-1 is associated with poor prognosis of astrocytomas. APMIS 2016; 124: 462-8.

28. Hu Z, Zhao P, Zhang K, Zang L, Liao H, Ma W. Evaluation of serum vascular adhesion protein-1 as a potential biomarker in thyroid cancer. Int J Endocrinol 2016; 2016: 6312529.

29. Muzza M, Degl'Innocenti D, Colombo C, Perrino M, Ravasi E, Rossi S, et al The tight relationship between papillary thyroid cancer, autoimmunity and inflammation: Clinical and molecular studies. Clin Endocrinol (Oxf) 2010; 72: 702-8.

30. Matsubayashi S, Kawai K, Matsumoto Y, Mukuta T, Morita T, Hirai K, et al. The correlation between papillary thyroid carcinoma and lymphocytic infiltration in the thyroid gland. J Clin Endocrinol Metab 1995; 80: 3421-4.

31. Kuo CY, Liu TP, Yang PS, Cheng SP. Characteristics of lymphocyte-infiltrating papillary thyroid cancer. Cancer Res. Pract 2017; 4: 95-99. 
32. HundahI SA, Fleming ID, Fremgen AM, Menck HR. A National cancer data base report on 53,856 cases of thyroid carcinoma treated in the U.S., 1985-1995. Cancer 1998; 83: 2638-48.

33. DeGroot LJ, Kaplan EL, Shukla MS, Salti G, Straus FH. Morbidity and mortality in follicular thyroid cancer. J Clin Endocrinol Metab 1995; 80: 2946-53.

34. Baloch ZW, Livolsi VA. Follicular-patterned lesions of the thyroid: the bane of the pathologist. Am J Clin Pathol 2002; 117: 143-50.

35. Salmi M, Tohka S, Berg EL, Butcher EC, Jalkanen S. Vascular adhesion protein 1 (VAP-1) mediates lymphocyte subtype-specific, selectin independent recognition of vascular endothelium in human lymph nodes. J Exp Med 1997; 186: 589-600.

36. Kurkijärvi R, Yegutkin GG, Gunson BK, Jalkanen S, Salmi M, Adams DH. Circulating soluble vascular adhesion protein 1 accounts for the increased serum monoamine oxidase activity in chronic liver disease. Gastroenterology 2000; 119: 1096-103.

37. Airas L, Mikkola J, Vainio JM, Elovaara I, Smith DJ. Elevated serum soluble vascular adhesion protein-1 (VAP-1) in patients with active relapsing remitting multiple sclerosis. J Neuroimmunol 2006; 177: 132-5. 